\title{
Risk of stroke and myocardial infarction after influenza-like illness in New York State
}

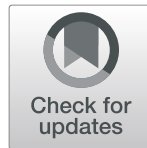

\author{
Erin R. Kulick ${ }^{1,2^{*}}$, Trevor Alvord ${ }^{3,4}$, Michelle Canning ${ }^{3,4}$, Mitchell S. V. Elkind ${ }^{3,4}$, Bernard P. Chang ${ }^{5}$ and \\ Amelia K. Boehme $e^{3,4}$
}

\begin{abstract}
Background: Influenza may be associated with increased stroke and myocardial infarction (MI) risk. We hypothesized that risk of stroke and MI after influenza-like illness (ILI) would be higher in patients in New York State. We additionally assessed whether this relationship differed across a series of sociodemographic factors.

Methods: A case-crossover analysis of the 2012-2014 New York Statewide Planning and Research Cooperative System (SPARCS) was used to estimate odds of ischemic stroke and MI after ILI. Each patient's case window (the time period preceding event) was compared to their control windows (same dates from the previous 2 years) in conditional logistic regression models used to estimate odds ratios and 95\% confidence intervals (OR, 95\% Cl). We varied the case windows from 15 to 365 days preceding event as compared to control windows constructed using the same dates from the previous 2 years. Analyses were stratified by sex, race, and urban-rural status based on residential zip code.
\end{abstract}

Results: A total of 33,742 patients were identified as having ischemic stroke and 53,094 had MI. ILI events in the 15 days prior were associated with a $39 \%$ increase in odds of ischemic stroke (95\% Cl 1.09-1.77), increasing to an almost $70 \%$ increase in odds when looking at ILI events over the last year ( $95 \% \mathrm{Cl} 1.56,1.83)$. In contrast, the effect of ILI hospitalization on MI was strongest in the 15 days prior ( $\mathrm{OR}=1.24,95 \% \mathrm{Cl} 1.06-1.44)$. The risk of ischemic stroke after ILI was higher among individuals living in rural areas in the 90 days prior to stroke and among men in the year prior to event. In contrast, the association between ILI and MI varied only across race with whites having significantly higher ILI associated Ml.

Conclusion: This study highlights risk period differences for acute cardiovascular events after ILI, indicating possible differences in mechanism behind the risk of stroke after ILI compared to the risk of MI. High risk populations for stroke after ILI include men and people living in rural areas, while whites are at high risk for MI after ILI. Future studies are needed to identify ways to mitigate these risks.

Keywords: Cardiovascular diseases, Influenza, Myocardial infarction, Stroke, Case-crossover, Health disparities

\footnotetext{
* Correspondence: erin.kulick@temple.edu

'Department of Epidemiology and Biostatistics, Temple University College of

Public Health, 1301 Cecil B Moore Avenue, Ritter Annex 904, Philadelphia, PA

19122, USA

${ }^{2}$ Department of Epidemiology, Brown University, Providence, RI, USA

Full list of author information is available at the end of the article
}

(c) The Author(s). 2021 Open Access This article is licensed under a Creative Commons Attribution 4.0 International License, which permits use, sharing, adaptation, distribution and reproduction in any medium or format, as long as you give appropriate credit to the original author(s) and the source, provide a link to the Creative Commons licence, and indicate if changes were made. The images or other third party material in this article are included in the article's Creative Commons licence, unless indicated otherwise in a credit line to the material. If material is not included in the article's Creative Commons licence and your intended use is not permitted by statutory regulation or exceeds the permitted use, you will need to obtain permission directly from the copyright holder. To view a copy of this licence, visit http://creativecommons.org/licenses/by/4.0/. The Creative Commons Public Domain Dedication waiver (http://creativecommons.org/publicdomain/zero/1.0/) applies to the data made available in this article, unless otherwise stated in a credit line to the data. 


\section{Background}

The morbidity and mortality associated with cardiovascular disease (CVD) is high. Heart Disease is the number one cause of death in the US, with approximately 735, 000 myocardial infarction (MI) events per year [1]. While the mortality from stroke has decreased, it is the fifth leading cause of death in the US and remains the leading cause of long-term adult disability with 800,000 stroke events annually $[1,2]$. Despite decreases in mortality, the morbidity associated with these diseases remains high, with a cost burden of approximately $\$ 17.5$ billion per year for direct stroke costs and $\$ 11.3$ billion for direct MI costs [1-3]. The reduction of risk factors for stroke and MI has become a high priority, with policy efforts implementing risk reduction efforts [3]. Traditional cardiovascular risk factors such as diabetes, smoking, high blood pressure, and sedentary behavior comprise only $80 \%$ of the risk associated with incident events. In addition, these factors are largely associated with long-term risk and do not account for short-term risk or a triggering event, i.e., the reason why an event occurs at a particular point in time, despite risk factors being present for years $[4,5]$. Therefore, with a substantial proportion of risk unexplained, identification of novel short term risk factors is of great importance.

Common infections, such as respiratory tract infections, have been identified as both an acute, short term trigger for stroke and MI and as a long-term chronic risk factor [6-15] . Respiratory tract infections are the most common cause of infection in adults, and "Influenza-like illness" (ILI) accounts for the majority of these infections [16]. Previous studies have shown significant associations between ILI and acute cardiovascular events, however no study has addressed these relationships in a large scale, generalizable dataset that allows for exploration of geographical, urban/rural, and racial-ethnic differences that could further influence these relationships. We hypothesized that ILI is associated with increased risk of incident stroke and MI in New York State. We additionally assessed whether this relationship differed by a series of sociodemographic factors and hypothesized that the risk of ILI associated event would be higher for men, minority populations, and those living in an urban environment.

\section{Methods}

\section{Study design}

We conducted a case-crossover analysis using 20122014 data from the New York State Department of Health Statewide Planning and Research Cooperative System (SPARCS) dataset, a comprehensive data reporting system that collects information on hospital admissions and emergency department (ED) visits within the state of New York. The SPARCS dataset collects information on approximately $98 \%$ of all hospitalizations in non-federal acute care facilities regardless of insurance status. Information on patient characteristics, diagnoses, treatments, services and charges is collected for each hospitalization or ED visit. Data elements include demographic information such as age, sex, race, and residential address. A unique patient ID ('upid') is assigned to each person to allow for tracking hospitalizations and ED visits over time. Diagnoses are established using International Classification of Disease (ICD-9) codes. The study populations contained all patients older than 18 years of age hospitalized for ischemic stroke or MI during 2014 in any of the non-federal acute care hospitals in New York State.

We employed a case-crossover design where each case served as his or her own control to investigate the association between acute cardiovascular events, specifically ischemic stroke and MI occurring in 2014, and preceding ILI events from 2012 to 2014. The case-crossover design is often used to study acute events, such as stroke or MI, triggered by an exposure that increases the risk for having an event transiently [17]. In this design, data from a short risk period prior to the event (case period) is compared to another time-period (control period) in the same individual. In addition, the use of a casecrossover design removes confounding by characteristics that do not vary over time and limits confounding by seasonality and long-term trends $[17,18]$. This strength is particularly important in a study of administratie 1ve health records that do not have detailed data on potential risk factors that may confound any association. Each patient's case window (the time period preceding event) was compared to their control windows (constructed using the same dates from the previous 2 years).

\section{Exposure assessment}

We defined ILI using previously described ICD-9 codes defined by the Department of Defense for the purposes of identifying ILI cases for surveillance [19]. Cases of ILI were defined as having one of the ICD-9 codes listed in Table 1 present on arrival at any diagnostic position for either an ED visit or a hospitalization for ILI. If no present on arrival indicator was available, we treated the diagnoses as in-hospital ILI and was not considered an exposure event. We used both inpatient and outpatient (ED) databases to capture ILI cases that were hospitalized and ILI cases that only presented to the ED department.

We defined an exposure event as both inpatient and outpatient admission for ILI in varying time intervals $(0-15,0-30,0-60,0-90,0-180,0-365$ days) prior to first stroke or MI event (defined as the case periods) and identical time intervals 1 and 2 years before the event (defined as the control periods), such that the calendar 
Table 1 ICD-9 Codes used to define Influenza-Like Illness (ILI)

\begin{tabular}{|c|c|c|c|}
\hline 079.89 & Viral infection NEC & 466 & Acute bronchitis and bronchiolitis \\
\hline 079.99 & Viral infection NOS & 466.0 & Acute bronchitis \\
\hline 460 & Acute nasopharyngitis & 466.1 & Acute bronchiolitis \\
\hline 462 & Acute pharyngitis & 466.19 & Acute bronchiolitis due to other infectious organism \\
\hline 464 & Acute laryngitis and tracheitis & 478.9 & Other and unspecified diseases of upper respiratory tract \\
\hline 464.0 & Acute laryngitis & 480 & Viral pneumonia \\
\hline 464.1 & Acute tracheitis & 487 & Influenza \\
\hline 464.10 & Acute tracheitis w/o obstruction & 487.0 & Influenza with pneumonia \\
\hline 464.2 & Acute laryngotracheitis & 487.1 & Influenza with other respiratory manifestation \\
\hline 464.20 & Acute laryngotracheitis w/o obstruction & 487.8 & Influenza with other manifestation \\
\hline 465 & Upper respiratory infection, multiple or unspecified sites & 490 & Bronchitis not specified as acute or chronic \\
\hline 465.0 & Acute laryngopharyngitis & 780.6 & Fever \\
\hline 465.8 & Upper respiratory infection of multiple sites & 784.1 & Throat pain \\
\hline 465.9 & Upper respiratory infection of unspecified sites & 786.2 & Cough \\
\hline
\end{tabular}

Adapted from Eick-Cost AA, Hunt DJ. 2015 Assessment of ICD-9-based case definitions for influenza-like illness surveillance. MSMR

time of the year remained constant across both case and control periods (Fig. 1).

\section{Outcome assessment}

We defined Ischemic stroke using ICD-9 codes validated in previous studies: 433. $\times 1$ (" $x$," the fourth digit, varies to specify arterial distribution), 434 (excluding $434 . \times 0$ ), or 436 at any diagnostic position. We excluded cases if "traumatic brain injury" ICD-9-CM code (800 to 804, 850 to 854 ) or "rehabilitation care" ICD-9-CM codes (V57) was present as the primary diagnosis [15, 20, 21]. MI was defined as ICD-9 code 410 present at any diagnostic position.

The SPARCS dataset does not provide distinguishable dates ICD-9 codes within the same admission, eliminating the ability of researchers to identify any temporal relationship of events within a singlefigur hospitalization. To guarantee all analyses were done between separate admissions for cardiovascular events and ILI, we removed all admissions for which stroke or MI and ILI occurred in the same admission from the analysis.

\section{Covariates}

The advantage to using a case-crossover design is that the study design accounts for traditional confounders in the analyses, with each case serving as their own control. We examined whether the association between ILI and cardiovascular events differed across a series of sociodemographic characteristics available in the SPARCS dataset including geographic location, race, and sex. We classified patients as living in urban versus rural communities based on their home ZIP code using Rural-Urban Commuting Area Codes (RUCA codes) previously assigned by the United States Department of Agriculture [22]. Urban ZIP codes included metropolitan communities with at least 50,000 residents. Rural ZIP codes included communities not connected to an urban center. Race, as entered into administrative records, was

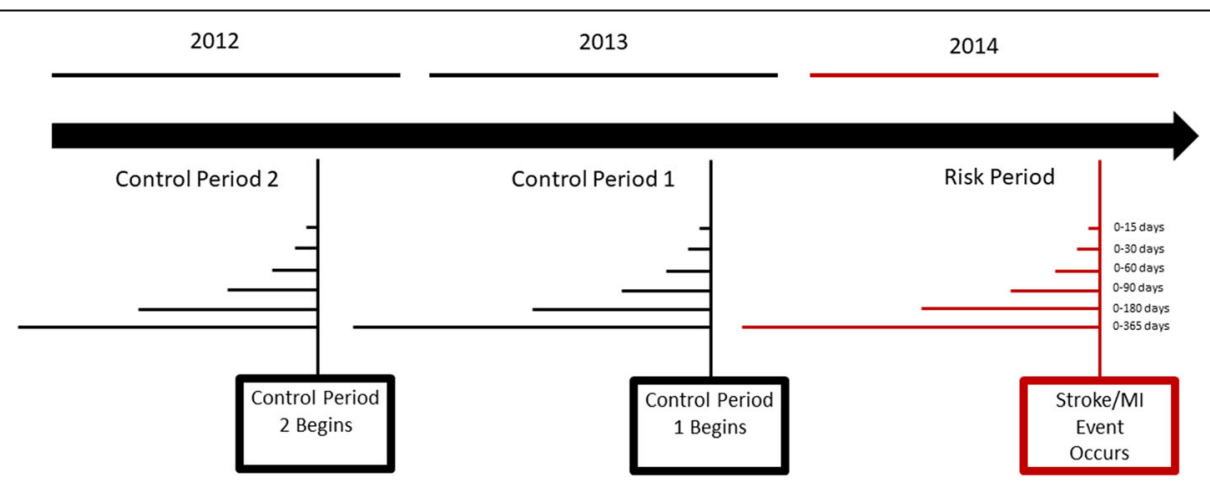

Fig. 1 Case-Crossover Study Design. Describes the case-crossover study design used in this analysis and compares the relationship between each patient's case window (the time -period preceding the cardiovascular event) to their control windows (constructed using the same calendar dates from the previous two years) 
Table 2 Baseline characteristics of patients with and without exposure to Influenza-Like-IIIness in 365-days prior to cardiovascular event

\begin{tabular}{|c|c|c|c|c|}
\hline & \multicolumn{2}{|l|}{$\begin{array}{l}\text { Ischemic Stroke } \\
(n=33,742)\end{array}$} & \multicolumn{2}{|c|}{ Myocardial Infarction $(n=53,094)$} \\
\hline & $\begin{array}{l}\text { Cases with exposure to ILI } \\
(n=2009)\end{array}$ & $\begin{array}{l}\text { Cases without ILI } \\
(n=31,733)\end{array}$ & $\begin{array}{l}\text { Cases with exposure to ILI } \\
(n=3773)\end{array}$ & $\begin{array}{l}\text { Cases without ILI } \\
(n=49,321)\end{array}$ \\
\hline Age (years) & 65.6 & 72.2 & 66.9 & 71.3 \\
\hline Standard deviation (range) & $16.4(18-101)$ & $14.6(18-104)$ & $15.3(18-109)$ & $14.4(18-111)$ \\
\hline Women, N (\%) & $1037(51.6 \%)$ & $16,213(51.1 \%)$ & $1714(45.4 \%)$ & $21,372(43.3 \%)$ \\
\hline \multicolumn{5}{|l|}{ Race, N (\%) } \\
\hline White & $910(45.6 \%)$ & $19,675(62.3 \%)$ & 2064 (54.9\%) & $34,243(69.7 \%)$ \\
\hline Black & $1099(54.7 \%)$ & $12,058(37.7 \%)$ & $1709(45.3 \%)$ & $15,078(30.3 \%)$ \\
\hline \multicolumn{5}{|l|}{ Residential Geography, N (\%) } \\
\hline Urban & 1795 (89.4\%) & $28,287(89.1 \%)$ & $3214(85.2 \%)$ & $42,736(86.7 \%)$ \\
\hline Rural & $214(10.6 \%)$ & 3446 (10.9\%) & $559(14.8 \%)$ & $6585(13.3 \%)$ \\
\hline
\end{tabular}

categorized into white versus black patients. Sex was dichotomized into male and female based on medical records.

\section{Statistical analysis}

We used conditional logistic regression stratified on individual ID variable "upid" to compute odds ratios (ORs) and 95\% confidence intervals (CI) for any inpatient admission for stroke or MI within 0-15 days, 0-30 days, 0-60 days, 0-180 days, and 0-365 days after exposure. We fit separate models to estimate the associations between ILI and ischemic stroke and MI.

While this study design did not allow for the investigation of time varying confounding, it has been shown in stroke and MI that limiting the control windows to a short time period (e.g. 2 years) reduces the bias from time varying confounders. For this scenario, two control periods were randomly selected from the two previous years, matching on month and date, to avoid overlap bias $[23,24]$.

To test whether the association of infections with cardiovascular event odds differs by available sociodemographic characteristics (sex, geography, or race), we included two-way interaction terms between each characteristic and ILI into individual conditional logistic regression models. Interaction terms with a $p$-value $\leq 0.10$ were considered potentially statistically significant [2527]. We then calculated stratum-specific estimates to look at differences in the relationship between ILI and cardiovascular events across rural/urban status, sex, and race.

\section{Results}

A total of 33,742 patients were identified as having an ischemic stroke and 53,094 had a MI in 2014 and were included in the analyses. Of those patients, 2009 (6\%) of ischemic strokes and $3773(7 \%)$ of MIs had at least one episode of ILI in the 365 days prior to event. On average, people who had an ILI event prior to a stroke or MI were younger and a higher proportion were black (Table 2).

The presence of an ILI hospitalization event within all period lengths was significantly associated with increased odds of ischemic stroke. Hospitalizations for ILI in the 15 days prior were associated with a $39 \%$ increase in odds of ischemic stroke $(\mathrm{OR}=1.39,95 \%$ CI 1.09-1.77), increasing to a $69 \%$ increase in odds when looking at ILI events over the last year $(\mathrm{OR}=1.69,95 \%$ CI $1.56,1.83)$ (Table 3). In contrast, the effect of ILI hospitalization on MI was significant in the 15 days prior to the event, with a $24 \%$ increase in odds of MI (OR $=1.24$, 95\% CI $1.06-$ 1.44), but decreasing slightly over the following 90 days. The strongest effect was seen when including at ILI events over the last year, increasing the odds of MI by $48 \%(\mathrm{OR}=1.48,95 \%$ CI 1.41, 1.57) (Table 3).

We next assessed whether the association between ILI and acute cardiovascular events differed across residential geography, sex, or race. In the first 30 days prior to an ischemic stroke event, the effect of ILI on risk of

Table 3 Cumulative odds ratios and 95\% Cl for ILI with risk of cardiovascular event

\begin{tabular}{|c|c|c|c|c|}
\hline \multirow[t]{2}{*}{ Hospitalization for ILI } & \multicolumn{2}{|c|}{ Ischemic Stroke } & \multicolumn{2}{|c|}{ Myocardial Infarction } \\
\hline & OR & $95 \% \mathrm{Cl}$ & OR & $95 \% \mathrm{Cl}$ \\
\hline 0-15 days before event & $1.39^{*}$ & $1.09,1.77$ & $1.24^{*}$ & $1.06,1.44$ \\
\hline 0-30 days before event & $1.48^{*}$ & $1.25,1.76$ & 1.07 & $0.96,1.20$ \\
\hline 0-60 days before event & $1.48^{*}$ & $1.29,1.69$ & 1.04 & $0.95,1.14$ \\
\hline 0-90 days before event & $1.59^{*}$ & $1.42,1.78$ & 1.07 & $0.99,1.15$ \\
\hline 0-180 days before event & $1.68^{*}$ & $1.53,1.85$ & $1.21^{*}$ & $1.14,1.29$ \\
\hline 0-365 days before event & $1.69^{*}$ & $1.56,1.83$ & $1.48^{*}$ & $1.41,1.57$ \\
\hline
\end{tabular}

*Indicates Statistical Significance at $p<0.05$. 
Table 4 Effect Modification of Association between ILI and Ischemic stroke by demographic and sociodemographic characteristics

\begin{tabular}{|c|c|c|c|c|c|c|c|c|c|}
\hline & \multicolumn{3}{|c|}{ Residential Geography } & \multicolumn{3}{|l|}{ Sex } & \multicolumn{3}{|l|}{ Race } \\
\hline & $\begin{array}{l}\text { Urban } \\
\text { OR }(95 \% \mathrm{Cl})\end{array}$ & $\begin{array}{l}\text { Rural } \\
\text { OR }(95 \% \mathrm{Cl})\end{array}$ & $\begin{array}{l}p \text {-value } \\
\text { for } \\
\text { interaction }\end{array}$ & $\begin{array}{l}\text { Men } \\
\text { OR }(95 \% \mathrm{Cl})\end{array}$ & $\begin{array}{l}\text { Women } \\
\text { OR }(95 \% \mathrm{Cl})\end{array}$ & $\begin{array}{l}p \text {-value } \\
\text { for } \\
\text { interaction }\end{array}$ & $\begin{array}{l}\text { Black } \\
\text { OR }(95 \% \mathrm{Cl})\end{array}$ & $\begin{array}{l}\text { White } \\
\text { OR }(95 \% \mathrm{Cl})\end{array}$ & $\begin{array}{l}p \text {-value } \\
\text { for } \\
\text { interaction }\end{array}$ \\
\hline $\begin{array}{l}0-15 \text { days before } \\
\text { event }\end{array}$ & $\begin{array}{l}1.38(1.08 \\
1.78)\end{array}$ & $\begin{array}{l}1.43(0.63 \\
3.22)\end{array}$ & 0.98 & $\begin{array}{l}1.57(1.13 \\
2.18)\end{array}$ & $\begin{array}{l}1.22(0.85 \\
1.72)\end{array}$ & 0.82 & $\begin{array}{l}1.40(0.88 \\
2.24)\end{array}$ & $\begin{array}{l}1.43(0.99 \\
2.04)\end{array}$ & 0.79 \\
\hline $\begin{array}{l}0-30 \text { days before } \\
\text { event }\end{array}$ & $\begin{array}{l}1.45(1.21 \\
1.75)\end{array}$ & $\begin{array}{l}1.65(1.05 \\
2.59)\end{array}$ & $0.10^{*}$ & $\begin{array}{l}1.82(1.43, \\
2.30)\end{array}$ & $\begin{array}{l}1.17(0.91 \\
1.51)\end{array}$ & $0.04^{*}$ & $\begin{array}{l}1.34(0.95 \\
1.89)\end{array}$ & $\begin{array}{l}1.47(1.15 \\
1.89)\end{array}$ & 0.56 \\
\hline $\begin{array}{l}0-60 \text { days before } \\
\text { event }\end{array}$ & $\begin{array}{l}1.48(1.28 \\
1.70)\end{array}$ & $\begin{array}{l}1.51(1.07 \\
2.12)\end{array}$ & 0.93 & $\begin{array}{l}1.65(1.37 \\
1.98)\end{array}$ & $\begin{array}{l}1.33(1.10 \\
1.60)\end{array}$ & 0.11 & $\begin{array}{l}1.36(1.05 \\
1.76)\end{array}$ & $\begin{array}{l}1.49(1.23 \\
1.80)\end{array}$ & 0.64 \\
\hline $\begin{array}{l}\text { 0-90 days before } \\
\text { event }\end{array}$ & $\begin{array}{l}1.56(1.38 \\
1.76)\end{array}$ & $\begin{array}{l}1.79(1.33 \\
2.41)\end{array}$ & 0.56 & $\begin{array}{l}1.75(1.49, \\
2.06)\end{array}$ & $\begin{array}{l}1.45(1.23 \\
1.69)\end{array}$ & 0.23 & $\begin{array}{l}1.56(1.25 \\
1.95)\end{array}$ & $\begin{array}{l}1.55(1.31 \\
1.82)\end{array}$ & 0.36 \\
\hline $\begin{array}{l}0-180 \text { days before } \\
\text { event }\end{array}$ & $\begin{array}{l}1.69(1.52 \\
1.87)\end{array}$ & $\begin{array}{l}1.63(1.29 \\
2.07)\end{array}$ & 0.87 & $\begin{array}{l}1.87(1.63, \\
2.14)\end{array}$ & $\begin{array}{l}1.53(1.34 \\
1.74)\end{array}$ & $0.08^{*}$ & $\begin{array}{l}1.71(1.42 \\
2.05)\end{array}$ & $\begin{array}{l}1.52(1.33 \\
1.74)\end{array}$ & 0.50 \\
\hline $\begin{array}{l}\text { 0-365 days before } \\
\text { event }\end{array}$ & $\begin{array}{l}1.71(1.57 \\
1.87)\end{array}$ & $\begin{array}{l}1.57(1.29 \\
1.91)\end{array}$ & 0.51 & $\begin{array}{l}1.73(1.54 \\
1.95)\end{array}$ & $\begin{array}{l}1.66(1.49, \\
1.84)\end{array}$ & 0.54 & $\begin{array}{l}1.64(1.41 \\
1.92)\end{array}$ & $\begin{array}{l}1.56(1.401, \\
1.744)\end{array}$ & 0.93 \\
\hline
\end{tabular}

*Indicates Statistical Significance at $p<0.05$

ischemic stroke was statistically significantly higher among individuals living in rural areas of New York State $(p$-value for interaction $=0.10)$ and among men $(p$ value for interaction $=0.04)$. There were also differences across sex in later time periods, with the effect of ILI on ischemic stroke stronger in men across a 180-day span $(p$-value for interaction $=0.08)($ Table 4$)$.

The association between ILI and MI varied significantly across race. In all time periods, the relationship between ILI and MI was significantly stronger among white individuals as compared to black individuals (Table 5). There were no significant differences across urban/rural status or sex.

\section{Discussion}

Our study found that ILI is a significant risk factor for acute cardiovascular events, including stroke and MI.
There is a $39 \%$ increased odds of stroke and $24 \%$ increased odds of MI during the first 15 days after ILI, however, this risk drops after 15 days for MI while it remains elevated for stroke. The odds of stroke or MI 1 year after ILI remains elevated, however, the risk was stronger for stroke than MI (69 and 48\% increased odds, respectively). This was predominantly driven by the risk in the first 15 days for MI. The timing of stroke and MI after ILI are consistent with prior reports that have highlighted how the risk for MI is higher shortly after ILI, while the risk of stroke remains increased for up to a year $[7,15]$.

To our knowledge, this is the first study to investigate whether the relationship between ILI and stroke, or ILI and MI, differs by sex, race-ethnicity, or by urban-rural status. We found the relationship between ILI and stroke was overall stronger for men and people living in rural

Table 5 Effect Modification of Association between ILI and Myocardial Infarction by demographic and sociodemographic characteristics

\begin{tabular}{|c|c|c|c|c|c|c|c|c|c|}
\hline & \multicolumn{3}{|c|}{ Residential Geography } & \multicolumn{3}{|l|}{ Sex } & \multicolumn{3}{|l|}{ Race } \\
\hline & $\begin{array}{l}\text { Urban } \\
\text { OR }(95 \% \mathrm{Cl})\end{array}$ & $\begin{array}{l}\text { Rural } \\
\text { OR }(95 \% \mathrm{Cl})\end{array}$ & $\begin{array}{l}p \text {-value } \\
\text { for } \\
\text { interaction }\end{array}$ & $\begin{array}{l}\text { Male } \\
\text { OR }(95 \% \mathrm{Cl})\end{array}$ & $\begin{array}{l}\text { Female } \\
\text { OR }(95 \% \mathrm{Cl})\end{array}$ & $\begin{array}{l}p \text {-value } \\
\text { for } \\
\text { interaction }\end{array}$ & $\begin{array}{l}\text { Black } \\
\text { OR }(95 \% \mathrm{Cl})\end{array}$ & $\begin{array}{l}\text { White } \\
\text { OR }(95 \% \mathrm{Cl})\end{array}$ & $\begin{array}{l}p \text {-value } \\
\text { for } \\
\text { interaction }\end{array}$ \\
\hline $\begin{array}{l}0-15 \text { days before } \\
\text { event }\end{array}$ & $\begin{array}{l}1.20(1.01 \\
1.42)\end{array}$ & $\begin{array}{l}1.41(0.99 \\
2.01)\end{array}$ & 0.26 & $\begin{array}{l}1.15(0.94 \\
1.41)\end{array}$ & $\begin{array}{l}1.35(1.07 \\
1.70)\end{array}$ & 0.91 & $\begin{array}{l}1.13(0.78 \\
1.62)\end{array}$ & $\begin{array}{l}1.63(1.32, \\
2.01)\end{array}$ & $0.08^{*}$ \\
\hline $\begin{array}{l}\text { 0-30 days before } \\
\text { event }\end{array}$ & $\begin{array}{l}1.02(0.90 \\
1.16)\end{array}$ & $\begin{array}{l}1.31(1.01 \\
1.69)\end{array}$ & 0.13 & $\begin{array}{l}1.02(0.88 \\
1.19)\end{array}$ & $\begin{array}{l}1.14(0.97 \\
1.36)\end{array}$ & 0.49 & $\begin{array}{l}0.91(0.69 \\
1.19)\end{array}$ & $\begin{array}{l}1.37(1.17 \\
1.60)\end{array}$ & $0.003^{*}$ \\
\hline $\begin{array}{l}\text { 0-60 days before } \\
\text { event }\end{array}$ & $\begin{array}{l}0.99(0.90 \\
1.09)\end{array}$ & $\begin{array}{l}1.28(1.04 \\
1.56)\end{array}$ & 0.17 & $\begin{array}{l}1.02(0.90 \\
1.14)\end{array}$ & $\begin{array}{l}1.08(0.94 \\
1.23)\end{array}$ & 0.71 & $\begin{array}{l}0.87(0.69 \\
1.08)\end{array}$ & $\begin{array}{l}1.33(1.18 \\
1.50)\end{array}$ & $0.0002^{*}$ \\
\hline $\begin{array}{l}\text { 0-90 days before } \\
\text { event }\end{array}$ & $\begin{array}{l}1.03(0.94 \\
1.12)\end{array}$ & $\begin{array}{l}1.25(1.04 \\
1.49)\end{array}$ & 0.67 & $\begin{array}{l}1.06(0.96 \\
1.18)\end{array}$ & $\begin{array}{l}1.07(0.95 \\
1.20)\end{array}$ & 0.75 & $\begin{array}{l}0.91(0.75 \\
1.09)\end{array}$ & $\begin{array}{l}1.34(1.21 \\
1.49)\end{array}$ & $<0.01^{*}$ \\
\hline $\begin{array}{l}\text { 0-180 days before } \\
\text { event }\end{array}$ & $\begin{array}{l}1.19(1.11, \\
1.28)\end{array}$ & $\begin{array}{l}1.31(1.13 \\
1.51)\end{array}$ & 0.90 & $\begin{array}{l}1.18(1.09 \\
1.29)\end{array}$ & $\begin{array}{l}1.25(1.14 \\
1.37)\end{array}$ & 0.91 & $\begin{array}{l}1.10(0.94 \\
1.28)\end{array}$ & $\begin{array}{l}1.44(1.32 \\
1.57)\end{array}$ & $0.001^{*}$ \\
\hline $\begin{array}{l}\text { 0-365 days before } \\
\text { event }\end{array}$ & $\begin{array}{l}1.46(1.37 \\
1.55)\end{array}$ & $\begin{array}{l}1.587(1.41 \\
1.79)\end{array}$ & 0.56 & $\begin{array}{l}1.43(1.33 \\
1.54)\end{array}$ & $\begin{array}{l}1.55(1.43 \\
1.68)\end{array}$ & 0.74 & $\begin{array}{l}1.29(1.13 \\
1.46)\end{array}$ & $\begin{array}{l}1.69(1.58, \\
1.82)\end{array}$ & $0.002^{*}$ \\
\hline
\end{tabular}

*Indicates Statistical Significance at $p<0.05$. 
areas, but differences were marked in the 90 days prior to stroke event. We found no difference in the relationship between ILI and stroke by race/ethnicity. The overall risk of stroke is higher in men and people living in rural areas which could explain some of the increased risk of stroke after ILI in these groups. However, the relationship between ILI and stroke did not differ between racial groups, despite stroke risk differing by race-ethnicity.

This was opposite to the findings for MI, where the relationship between ILI and MI was strongest in White patients compared to Black patients in the year prior to the event. We saw no difference in the ILI-MI relationship by sex or urban/rural status. These findings could be a reflection of differences in factors such as socioeconomic status and decreased access to health systems, as opposed to biological mechanisms [28]. It could be possible that people with stroke risk factors have more access to care- therefore adding to a higher probability of being vaccinated. Additional study is needed to evaluate whether the relationship between ILI and stroke/MI is different in people with diabetes or chronic heart failure, and whether there are additional patient characteristics that are associated with greater risk of stroke or MI after ILI. Additionally, these findings could be a reflection of regional influenza vaccine usage in NY State, as vaccination for influenza has been shown to reduce the risk of stroke and MI after ILI [10]. Women, people living in urban areas, and people with cardiovascular risk factors are more likely to be vaccinated for influenza [10]. Despite this, influenza vaccination in adults in NY state remains below the Centers for Disease Control goal of $90 \%$ with a range of $33-67 \%$ vaccinated depending on age group, with vaccinations increasing with age.

Proposed mechanisms behind the relationship between ILI and stroke or MI include mediation through a prothrombotic state, inflammation-mediated injury of endothelium, or through effects on cardiac endothelium [6, 10-13]. The relationship between the innate immune system and stroke risk has been long described. While the mechanism of stroke risk remains poorly understood, several hypotheses implicate an increased immune response as a potential mechanism for the increased stroke risk. Additional explanations include polymorphisms in the toll-like receptor 4 gene (TLR4), involved in the innate immune system's response to both bacterial pathogens and influenza [29-31].

The increasing recognition of the importance of inflammatory pathways in stroke and cardiovascular disease is consistent with a possible role of peptide sharing-based cross-reactivity as contributing factors to cerebrovascular damage [32]. The results of this study suggest the population at risk for MI post-infection is different than the population at risk for stroke post-infection due to the differences in the risk periods. While overlap exists between the two populations in terms of risk, the two outcomes need to be assessed separately to distinguish the most atrisk populations, to target potential interventions for future studies to the appropriate at-risk groups. The degree of stroke risk can vary significantly from person to person, however, the use of the case-crossover study is a strength in this regard. More research should be performed on the risk of stroke and MI after ILI to determine which preventative measures are most appropriate for reducing stroke and MI risk after ILI. Future studies are needed to evaluate whether the differences in risk for stroke versus MI after ILI by subgroups provide insight into potential differences in mechanisms, including social, behavioral, or biologic mechanisms.

There were several limitations to our study. The use of an administrative dataset limits us to defining the outcomes, exposures, and covariates based on ICD-9 codes. While these ICD-9 codes have been validated, there was the potential for misclassification. For example, we did not have information on severity of illness, or on outpatient visits or treatments. A key limitation of this study is that we are only able to identify ILI cases severe enough to require treatment in the ED or inpatient settings and likely biasing the effect of ILI on stroke and MI towards the null. Additionally, we did not have any information on influenza vaccination. We did not expect any outcome misclassification to be associated with ILI and any resulting bias, therefore, would bias our results toward the null. The case-crossover design also does not account for the increased risk associated with the aging of the patient over time, their concomitant development of new risk factors (e.g. newly diagnosed diabetes etc.), or cases of ILI or other infection that did not warrant a visit to the ED. To attempt to address this, we limited the control periods to 2 years. Despite these limitations, the use of the NY State DOH SPARCS data provides information on nearly all in-hospital admissions regardless of insurance status resulting in a large, generalizable study. The case-crossover design reduces the influence of confounders on the measures of association. The ability to explore group differences in the relationship between ILI, stroke and MI identified at risk groups who could be targeted for future interventions in decreasing the risk of stroke or MI after ILI.

\section{Conclusions}

Our study highlights risk period differences for acute cardiovascular events after ILI, potentially indicating differences in mechanism behind the risk of stroke after ILI compared to the risk of MI after ILI. We found that high risk populations for stroke after ILI include men and people living in rural areas, while whites are at high risk for MI after ILI. Future studies building on this data may help identify targeted interventions to mitigate these risks. 


\section{Abbreviations}

MI: Myocardial infarction; ILI: Influenza-like-illness; SPARCS: New York statewide planning and research cooperative system; OR: Odds ratio; Cl: Confidence intervals; CVD: Cardiovascular disease; ED: Emergency department; ICD-9: International classification of disease; RUCA codes: Ruralurban commuting area codes

\section{Acknowledgements}

This study was first published as an abstract at the International Stroke Conference.

Alvord T, Kulick ER, Canning M, Elkind MS, Boehme AK. Abstract 189: Influenza-Like IIIness and Risk of Stroke in New York State. International Stroke Conference, 2019

\section{Authors' contributions}

ERK assisted in conceptualization of study, analyzed and interpreted data, and was a major contributor in writing the manuscript. TA assisted in analysis and interpretation of data, assisted in writing and revision of manuscript. MC assisted in interpretation of data and revision of manuscript for intellectual content. MSE interpreted the data, revised the manuscript for intellectual content. BPC gave clinical expertise and revised the manuscript for intellectual content. AKB designed and conceptualized study, interpreted the data, major role in acquisition of data, revised the manuscript for intellectual content. All authors have read and approved the final manuscript.

\section{Funding}

This work was supported by the National Institutes of Health National Heart, Lung, and Blood Institute (T32HL13462, Dr. Kulick; R01 HL1469 and R01 HL141811, Dr. Chang) and National Institute of Neurological Disorders and Stroke (R03 NS10141 and R21 MD01245, Dr. Boehme). Dr. Elkind serves on the National, Founders Affiliate, and New York City chapter boards of the American Heart Association/American Stroke Association; and receives royalties from UpToDate for chapters related to cryptogenic stroke. The content is solely the responsibility of the authors and the funding bodies (NHLBI, NINDS, NIH, or AHA/ASA) had no role in the design of the study and collection, analysis, and interpretation of data and in writing the manuscript.

\section{Availability of data and materials}

The data that support the findings of this study are available from the New York State Department of Health and are available by written request and after research proposal is approved. Restrictions apply to the availability of these data, which were used under license for the current study, and are not publicly available. Data are available from the authors upon reasonable request and after obtaining permission from the New York State Department of Health.

\section{Declarations}

\section{Ethics approval and consent to participate}

This study (IRB-AAAR0877) was approved by the institutional review board at Columbia University Medical Center; the need for review was waived as data used were did not contain direct personal identifiers.

\section{Consent for publication}

Not applicable.

\section{Competing interests}

Authors report no conflicts of interest.

\section{Author details}

'Department of Epidemiology and Biostatistics, Temple University College of Public Health, 1301 Cecil B Moore Avenue, Ritter Annex 904, Philadelphia, PA 19122, USA. ${ }^{2}$ Department of Epidemiology, Brown University, Providence, Rl, USA. ${ }^{3}$ Department of Neurology, Vagelos College of Physicians and Surgeons, Columbia University, New York City, NY, USA. ${ }^{4}$ Department of Epidemiology, Mailman School of Public Health, Columbia University, New York, NY, USA. ${ }^{5}$ Department of Emergency Medicine, Vagelos College of Physicians and Surgeons, Columbia University, New York City, NY, USA.
Received: 8 July 2020 Accepted: 26 April 2021

Published online: 05 May 2021

\section{References}

1. Benjamin EJ, Blaha MJ, Chiuve SE, Cushman M, Das SR, Deo R, et al. Heart disease and stroke statistics-2017 Update: a report from the American heart association. Circulation. 2017;135(10):e146-603.

2. National Stroke Association. Stroke 101: Fast facts on stroke [Internet]. Available from: http://www.stroke.org/sites/default/files/resources/NSA FactSheet_Stroke_101_2014.pdf.

3. Ovbiagele B, Goldstein LB, Higashida RT, Howard VJ, Johnston SC, Khavjou $\mathrm{OA}$, et al. Forecasting the future of stroke in the United States. Stroke. 2013; 44(8):2361-75.

4. Bang OY, Ovbiagele B, Kim JS. Nontraditional risk factors for ischemic stroke: an update. Stroke. 2015;46(12):3571-8. https://doi.org/10.1161/STROKEA HA. 115.010954 .

5. Pearson TA, Palaniappan LP, Artinian NT, Carnethon MR, Criqui MH, Daniels SR, Fonarow GC, Fortmann SP, Franklin BA, Galloway JM, Goff Jr DC, Heath GW, Frank ATH, Kris-Etherton PM, Labarthe DR, Murabito JM, Sacco RL, Sasson C, Turner MB American heart association guide for improving cardiovascular health at the community level, 2013 update: a scientific statement for public health practitioners, healthcare providers, and health policy makers introduction and background for the community . Circulation 2013:127:0-0, 16, 1730, 1753, DOl: https://doi.org/10.1161/CIR.0b013e3182 8 8f894.

6. Elkind MSV, Carty CL, O'Meara ES, Lumley T, Lefkowitz D, Kronmal RA, et al. Hospitalization for infection and risk of acute ischemic stroke: the cardiovascular health study. Stroke. 2011;42(7):1851-6. https://doi.org/10.11 61/STROKEAHA.110.608588

7. Warren-Gash C, Hayward AC, Hemingway H, Denaxas S, Thomas SL, Timmis $A D$, et al. Influenza infection and risk of acute myocardial infarction in England and wales: a CALIBER self-controlled case series study. J Infect Dis. 2012;206(11):1652-9. https://doi.org/10.1093/infdis/jis597.

8. Rothman RE, Hsieh YH, Yang S. Communicable Respiratory Threats in the ED: Tuberculosis, Influenza, SARS, and Other Aerosolized Infections. Emerg Med Clin North Am. 2006;24(4):989-1017. Published online 2006 Sep 16. https://doi.org/10.1016/j.emc.2006.06.006.

9. Bova IY, Bornstein NM. Korczyn. Acute infection as a risk factor for ischemic stroke. Stroke. 1996;27(12):2204-6. https://doi.org/10.1161/01.STR.27.12.2204.

10. Smeeth $\mathrm{L}$, Thomas $\mathrm{SL}$, Hall AJ, Hubbard R, Farrington P, Vallance P. Risk of myocardial infarction and stroke after acute infection or vaccination. N Engl J Med. 2004;351(25):2611-8. https://doi.org/10.1056/NEJMoa041747.

11. Syrjänen J, Valtonen $W$, livanainen $M$, Kaste $M$, Huttunen JK. Preceding infection as an important risk factor for ischaemic brain infarction in young and middle aged patients. Br Med J (Clin Res Ed). 1988;296(6630):1156-60.

12. Syriänen J. Central nervous system complications in patients with bacteremia. Scand J Infect Dis. 1989;21(3):285-96. https://doi.org/10.3109/ 00365548909035698

13. Zurrú MC, Alonzo C, Brescacín L, Romano M, Cámera LA, Waisman G, et al Recent respiratory infection predicts atherothrombotic stroke: case-control study in a Buenos Aires healthcare system. Stroke. 2009;40(6):1986-90 https://doi.org/10.1161/STROKEAHA.108.535559.

14. Arcari CM, Gaydos CA, Nieto FJ, Krauss M, Nelson KE. Association between chlamydia pneumoniae and acute myocardial infarction in young men in the United States military: the importance of timing of exposure measurement. Clin Infect Dis. 2005:40(8):1123-30. https://doi.org/10.1086/42 8730.

15. Boehme AK, Luna J, Kulick ER, Kamel H, Elkind MSV. Influenza-like illness as a trigger for ischemic stroke. Ann Clin Transl Neurol. 2018;5(4):456-63. https:// doi.org/10.1002/acn3.545.

16. Thompson WW, Shay DK, Weintraub E, Brammer L, Bridges CB, Cox NJ, et al. Influenza-associated hospitalizations in the United States. J Am Med Assoc. 2004:292(11):1333-40. https://doi.org/10.1001/jama.292.11.1333.

17. Maclure $\mathrm{M}$. The case-crossover design: a method for studying transient effects on the risk of acute events. Am J Epidemiol. 1991;133(2):144-53. https://doi.org/10.1093/oxfordjournals.aje.a115853.

18. Bateson TF, Schwartz J. Selection Bias and confounding in case-crossover analyses of environmental time-series. Vol. 12, Source: Epidemiology. 2001

19. Eick-Cost AA, Hunt DJ. Assessment of ICD-9-based case definitions for influenza-like illness surveillance. MSMR. 2015;22(9):2-7. 
20. Kokotailo RA, Hill MD. Coding of stroke and stroke risk factors using international classification of diseases, revisions 9 and 10. Stroke. 2005;36: 1776-81.

21. Tirschwell DL, Longstreth WT. Validating administrative data in stroke research. Stroke. 2002;33(10):2465-70. https://doi.org/10.1161/01.STR. $0000032240.28636 . \mathrm{BD}$

22. U.S. Department of Agriculture - Economic Research Service. Documentation - 2010 Rural-Urban Commuting Area (RUCA) Codes [Internet]. Available from: https://www.ers.usda.gov/data-products/rural-urba n-commuting-area-codes/documentation/

23. Janes H, Sheppard L, Lumley T. Overlap bias in the case-crossover design, with application to air pollution exposures. Stat Med. 2005;24(2):285-300. https://doi.org/10.1002/sim.1889.

24. Mittleman MA. Optimal referent selection strategies in case-crossover studies: a settled issue. Epidemiology. 2005:16:715-6.

25. Marshall SW. Power for tests of interaction: effect of raising the type I error rate. Epidemiol Perspect Innov. 2007:4(1):4. https://doi.org/10.1186/17425573-4-4.

26. Burke JF, Sussman JB, Kent DM, Hayward RA. Three simple rules to ensure reasonably credible subgroup analyses. BMJ. 2015;351:h5651. [cited 2021 Mar 19]. Available from: http://www.bmj.com/.

27. Greenland S. Tests for interaction in epidemiologic studies: a review and a study of power. Stat Med. 1983;2(2):243-51. https://doi.org/10.1002/sim.4 780020219.

28. Vogel TR. Update and review of racial disparities in sepsis. In: Surgical Infections. 2012. p. 203-8.

29. Kiechl S, Lorenz E, Reindl M, Wiedermann CJ, Oberhollenzer F, Bonora E, et al. Toll-like receptor 4 polymorphisms and Atherogenesis. N Engl J Med. 2002;347(3):185-92. https://doi.org/10.1056/NEJMoa012673.

30. Olejnik J, Hume AJ, Mühlberger E. Toll-like receptor 4 in acute viral infection: too much of a good thing. PLoS Pathogens. 2018;14:e1007390.

31. Carty M, Bowie AG. Recent insights into the role of Toll-like receptors in viral infection. Clin Exp Immunol. 2010;161:397-406.

32. Lucchese G, Flöel A, Stahl B. Cross-reactivity as a mechanism linking infections to stroke. Front Neurol. 2019:10(MAY):469.

\section{Publisher's Note}

Springer Nature remains neutral with regard to jurisdictional claims in published maps and institutional affiliations.

Ready to submit your research? Choose BMC and benefit from:

- fast, convenient online submission

- thorough peer review by experienced researchers in your field

- rapid publication on acceptance

- support for research data, including large and complex data types

- gold Open Access which fosters wider collaboration and increased citations

- maximum visibility for your research: over $100 \mathrm{M}$ website views per year

At BMC, research is always in progress.

Learn more biomedcentral.com/submissions 